\title{
Designing Context-Based Video Instruction in Enhancing the Conceptual Understanding of Grade XI Students
}

\author{
Russel T. Soltura ${ }^{1 *}$ (iD \\ ${ }^{1}$ Department of Education - Quezon, Lucena City, Quezon Province, Philippines \\ *Corresponding author: russel.soltura@ deped.gov.ph
}

\begin{abstract}
Abstrak
Penelitian ini secara umum bertujuan untuk merancang pembelajaran video berbasis konteks sesuai dengan kerangka TPACK untuk meningkatkan pemahaman konseptual siswa tentang biologi sel. Studi saat ini menilai tingkat pemahaman konseptual dari 73 siswa kelas 11-responden dari Quezon Science High School dalam biologi sel sebelum pemanfaatan instruksi video berbasis konteks. Ini berusaha untuk menguji perbedaan yang signifikan antara nilai pretest dan posttest dalam disiplin tersebut. Penelitian ini mengidentifikasi tingkat akseptabilitas pembelajaran video berbasis konteks seperti yang dirasakan oleh siswa-responden dalam hal tujuan pembelajaran, akurasi, daya tarik, kejelasan, dan kegunaan. Responden terdaftar di STEM Strand SMA S.Y. 2020 - 2021. Kuesioner dan instruksi video konteks dikembangkan dan divalidasi untuk menilai dan mengevaluasi tujuan penelitian dari penelitian ini. Topik-topik dalam biologi sel memperoleh nilai MPS keseluruhan sebesar 31,15\%. Artinya, siswa-responden memiliki miskonsepsi tertentu tentang konsep yang berbeda dalam topik tersebut sebelum pemanfaatan sumber belajar digital tersebut. Kesesuaian bahasa, penampilan umum guru, kualitas video, pencahayaan, animasi, dan transisi video adalah beberapa parameter yang dipertimbangkan dalam merancang video ceramah. Nilai t keseluruhan sebesar 59,57 lebih besar dari nilai tabular sebesar 1,99. Ini menyiratkan bahwa instruksi video berbasis konteks yang dikembangkan dalam meningkatkan pemahaman konseptual dalam biologi sel adalah alat yang valid dalam proses belajar-mengajar. Selanjutnya, video instruksi berbasis konteks yang dikembangkan dalam meningkatkan pemahaman konseptual terpuji untuk digunakan dalam hal tujuan pembelajaran, kejelasan, akurasi, daya tarik, dan kegunaan.
\end{abstract}

Kata kunci: Pemahaman Konseptual, Pembelajaran Video Berbasis Konteks, Biologi Sel

\section{Abstract}

This study generally aims to design context-based video instruction in accordance to TPACK framework in order to enhance the conceptual understanding of the students with regards to cell biology. The current study assessed the level of conceptual understanding of 73 Grade 11 student-respondents of Quezon Science High School in cell biology prior to the utilization of context-based video instruction. It sought to test the significant difference between the pretest and posttest scores in the said discipline. This study identified the level of acceptability of the context-based video instruction as perceived by the studentrespondents in terms of learning objectives, accuracy, appeal, clarity, and usability. The respondents are enrolled in STEM strand of Senior High School, S.Y. 2020 - 2021. Questionnaires and the context-video instruction were developed and validated to assess and evaluate the research objectives of this study. The topics in cell biology obtained an overall MPS value of $31.15 \%$. It means that the student-respondents have specific misconceptions about the different concepts in the said topic prior to the utilization of the said learning digital resources. The appropriateness of the language, general appearance of the teacher, quality of video, lighting, animation, and video transitions were some of the parameters considered in designing the video lectures. The overall $\mathrm{t}$-value of 59.57 is greater than the tabular value of 1.99 . It implies that the developed context-based video instruction in enhancing the conceptual understanding in cell biology is a valid tool in the teaching-learning process. Furthermore, the developed context-based video instruction in enhancing the conceptual understanding is commendable for use in terms of learning objectives, clarity, accuracy, appeal, and usability.

Keywords: Extent of Usage, Internet, Reading, Undergraduate Students, Gender, Specialization

\begin{tabular}{ll}
\hline History: & Publisher: Undiksha Press \\
Received : August 12, 2021 & Licensed: This work is licensed under \\
Revised : August 13, 2021 & a Creative Commons Attribution 3.0 License \\
Accepted : September 12, 2021 &
\end{tabular}

\section{INTRODUCTION}

The World Health Organization (WHO) has announced that COVID-19 pandemic is a major public health concern in the world community nowadays. The said health concern served as the major challenge in the international education systems (Abidah et al., 2020; Sutiah et al., 2020). The different sectors of the government declared that different 
institutions to cease face-to-face classroom instruction for most of the learners and teachers. Thus, they are required to shift to distance learning. Based from the major findings from the previous studies, the implementation of distance learning still has many challenges (Bower, B., 2001; Christo-Baker, 2004; Fojtik, 2018; Kebritchi et al., 2017; Mapuva, 2009; Mathew, I. \& Ebelelloanya, 2016; Musingafi et al., 2015; O'Donoghue et al., 2004). One of the major challenges and issues in distance learning based from the experiences of the students is that self-study occasionally escape information, leading to difficulties in conceptual understanding of the topic (Alea et al., 2020; Fojtik, 2018). A previous study revealed that survey data emphasized that learners considered cell biology as one of the difficult disciplines to understand (Duda \& Adpriaydi., 2020). In addition, if the said problem was not addressed, the difficulties in conceptual understanding will serve as a major hindrance for the students to further learn the different biological processes.

Several studies did not consider the other possible solutions to overcome the difficulty in conceptual understanding leading to misconceptions. Furthermore, the previous studies established the students' views about the said discipline and the factors that affect them, their findings raised such question including the formulation of a solution to the problem through the use of context-based video instruction as an integral part of Technological Pedagogical Content Knowledge (TPACK) Framework (Feladi et al., 2020; Mavrikaki et al., 2012). The use of context-based video instruction is best used to instruct and guide the learners to reach a better, more robust understanding of the subject matter (Harris \& Hofer, 2011; Nursyifa et al., 2020). Hence, this current study will investigate this problem as it extends the previous researches with regards to providing a solution in order to enhance the conceptual understanding in cell biology through the use a context-based video instruction in the teaching-learning process.

In this study, the concept of cell biology served as the main highlight since it was stated in several studies that the abstract nature of the said topic will lead to difficulties in conceptual understanding of the lesson especially in the field of cell biology since the learners cannot visualize the concepts directly. Thus, it is difficult for them to recall the main ideas of the lessons (Duda \& Adpriaydi., 2020). Furthermore, it can lead to several misconceptions that must be addressed in the teaching-learning process. They stated in their study that the concepts of cell biology is considered to be difficult to understand as perceived by the students. Low learning outcomes were reported also from their point of views. There is an incorrect relationship error among the different concepts, intuitive ideas or wrong views. This idea can describe the difficulties in conceptual understanding of the topic which is strongly connected to misconceptions (Suparno, 2013). In addition, he summarized the causes of difficulties in conceptual understanding of the topics into five (5) groups, namely: students, teachers, textbooks, contexts, and teaching methods.

Students experience several difficulties in conceptual understanding because of the misinterpretation about the different natural phenomena in their everyday lives (Duda \& Adpriaydi., 2020). The use of many vocabulary terms about life and living organisms in the colloquial language and the use of these terms in a meaning aside from the defined scientific equivalent was considered to be among the problems that make learning and teaching cell biology difficult (Gungor \& Ozkan, 2017). Moreover, these difficulties emerge along the teaching-learning process. It can lead to confusion on the part of the students in understanding scientific phenomena and conducting scientific explanations. If this problem was not solved, this will serve a one of the major barriers for the learners to grasp and comprehend the learning process. Previous studies emphasized in their study that $8.81 \%$ of the total number of respondents perceived that the topics "cell structure" and "cell division" are difficult and it can be attributed to the complexity of the topics, students' learning habits, as well as the teachers' problems in the teaching process in the planning, implementation, and 
evaluation stages (Etobro \& Fabinu, 2017; Hadiprayitno et al., 2019). Additionally, they revealed that the sources of difficulty of the perceived difficult topics to abstractness, complexity, misconception of topics, unavailable instructional materials, poor attitude of teachers to teaching, lack of practical classes and poor students' study habits. The teaching methods including the biological level of organization and the abstract level of the concepts as reasons for encountering difficulties in conceptual understanding in biology (Zeidan, 2010). Another reason for such difficulty is that biology learning is generally based on memorization. As a result, it makes biology hard for the students to learn (Cimer, 2004; Durmaz, 2007; Saka, 2006). As a result, the continuation of these problems make the students to become more passive rather than active learners. It does not foster meaningful learning and long-term information retention of some abstract concepts in biology (Ahmed, 2009; Ahmed \& Abimbola, 2011; Umar, 2011). In order to solve these underlying issues and concerns in relation to difficulties in conceptual understanding in biology, learners who were exposed to information with the help of dynamic representations of different biological concepts have higher learning outcomes (Höffler \& Leutner, 2007). This can be done through the use of context-based video instructions that will provide the potential to enhance learners' retention and motivation related to cell biology (Choi \& Johnson, 2010).

Video-based instruction is an ideal form of technology for online distance learning, especially, as an alternative method for asynchronous class when face-to-face learning is not possible. It was stated that there are two (2) methods in order to deliver video-based instruction: through the use of a camera or by unique technology called video capture/screencast (Ghilay, 2017, 2018). Video capture is an excellent alternative way to video camera recording and it can provide the students even more dynamic and exciting contents. In addition, since the video clips can be paused or reviewed anytime, anywhere, students can perform advance lessons at their own pace which is essential for the development in the learning process. Nowadays, many educators in their respective fields utilize video-based instruction as their form of technology for the discussions of topic, such as computer programming languages, instructional design and technology, object-oriented programming, mathematical modeling, and nursing (Ellington \& Hardin, 2008; Lee et al., 2008; Phillips \& Billings, 2007; Sugar et al., 2010). These video instructions reveal specific actions associated with a specific subject area.

The use of video-based instruction in the learning process is significantly advantageous (Peterson, 2007). The wide availability of smartphones and tablets including laptops and personal computers allows the learners to watch video instructions while overcoming time and location constraints (Campbell et al., 2010; Ghilay, 2018). Video-based instructions can be an efficient and effective alternative method to face-to-face learning (Pang, 2009; Traphagan et al., 2010). Moreover, there is as strong support with regards to the advantages in relation to the utilization of video instructions for students' learning process as alternative replacement to other methods of teaching (Campbell et al., 2010; De Koning et al., 2007; Gardner, 1983; Mayer, 2009; Smith \& Smith, 2012; Walker, 2010). Context-based video- instruction brings courses alive by allowing online learners to use their visual and auditory senses to learn complex concepts and difficult procedures (Hartsell \& Yuen, 2006). Based from the issues and concerns highlighted in several studies, educators should reconsider the appropriate teaching strategies at senior secondary school level. There is a need to utilize technology during the instruction to enhance and facilitate meaningful learning in biology (Gambari et al., 2014). In order to ensure a captivating approach that will assists the learners to understand the different biological concepts is through the use of multimedia presentations in visual and verbal formats with the integration of pictures, animations, texts, and narrations (Adegoke, 2010). Likewise, learners acquired better understanding as well as information retention and developed comprehension skills more as compared to the other 
groups during the discussion about genetics through the use of multimedia (Starbek et al., 2010). It is also similar to the findings in which they figured out that learners who were taught food and nutrition and pupils taught science at nursery and primary school levels, performed better and had better retention than those other group of learners who are exposed to traditional methods of teaching respectively (Achebe, 2008; Gambari \& Zubairu, 2008). Learners who studied Computer-Aided Design (CAD) exposed to video-based instructions, have better performance in the said course than those groups of students who studied the same contents using traditional textbooks (Smith \& Smith, 2012). For instance, the computer animation learning courseware had positive impact to the learners' academic performance and achievement level (high and low) (Nusir et al., 2010). Hence, teachers should expose biology students to video-based multimedia instructional strategies in order to foster effective and active learning process (Gambari et al., 2014). Video lectures arouse the interest of the learners, enables them to learn basic science concepts, enhances lecture-discussion and students' comprehension, helps them easily understand the lesson, and provides meaningful examples, relevant information and visual presentation (Rodriguez \& Ang, 2020).

This study generally aims to enhance the conceptual understanding among the Grade 11 students in cell biology through the use of context-based video instruction. Specifically, this study sought: to assess the level of conceptual understanding among student-respondents in terms of the topics in cell biology; to design a context-based video instruction that will enhance the conceptual understanding in cell biology among the student-respondents; to determine if there is significant difference between the pretest and posttest scores of the student-respondents; and to find out the level of acceptability of the developed context-based video instruction as perceived by the student-respondents in terms of learning objectives, accuracy, clarity, appeal, and usability.

\section{METHODS}

This research study used the pre-experimental type of research specifically one-group pretest-posttest design. This method was used in such a way that the group was pretested. Afterwards, the treatment (i.e., context-based video instruction) was employed to the group and the posttest was administered. During this phase of the study, it examined the significant difference of the raw scores between the pretest and posttest scores. This will serve as strong evidence to prove the validity of the said context-based video instruction. This study was conducted at Quezon Science High School (QSHS). It is a science-oriented public secondary school located along Diversion Road, Brgy. Isabang, Tayabas City. The said school consisted of 446 enrollees from Grade 7 to Grade 12. These students came from the four (4) congressional districts of Quezon Province. The school aims to produce students who are both academically inclined and substantially trained in the basic work skills making them globally competitive and value-oriented through relevant and responsive curriculum.

There are several research instruments that were used in the study to achieve such reliable and valid results and discussions which are essential for the attainment of the desirable objectives. To design the context-based video instruction, the researcher utilized several literary sources like books, electronic references, least mastered competencies and other existing modules that provide a glimpse related to the concept to acquire some ideas and concepts that eventually resulted to the plan on how this topic will be constructed. The said digital learning material includes: The Cell Theory, Cellular Structure and Functions, Animal and Plant Cells, Prokaryotic and Eukaryotic Cells, Mitosis, Meiosis, Cell Cycle Control System, Plasma Membrane, and Cell Transport Mechanisms. These topics were based on the Most Essential Learning Competencies (MELCs) anchored on the General Biology 1 Curriculum Guide. 
Afterwards, the context-based video instruction was developed. The researcher gathered a wide variety of reference materials to develop the said instructional material dealing with the concept about cell biology. Several literary sources were employed as support of each item contained within the said instructional material. Lastly, the researcher asked permission from the panel of experts, specifically, science teachers of the said institution to conduct content validation of the said material. In addition, the researcher consulted an ICT expert for the validation of the said video instruction based on the following parameters: appropriateness of language, general appearance of the lecturer, editing, video quality, and lighting. All suggestions and modifications regarding the content of the materials were considered in the study.

The researcher constructed an achievement test that consist of multiple-choice type, identification, and restricted-response tests to determine if the developed context-based video instruction had a positive impact on the students' performance level, specifically, in understanding the concepts dealing with cell biology. This achievement test was taken as the pretest and posttest after the student-respondents utilized the said instructional material. All of the questions in the said assessment were categorized within the Remembering, Understanding, and Applying levels based from the revised Bloom's Taxonomy of Learning Objectives. In constructing the achievement test, the researcher consulted the master teacher of Science and Technology Department of the said institution for evaluation and validation with regards to test construction. Thus, several modifications were followed. In order to find out the level of acceptability of the context-based video instruction in enhancing the conceptual understanding in cell biology, the researcher adapted the modified questionnaire in a form of a Likert Scale. The format of this scale was a typical four (4)-level one namely strongly agree, agree, disagree and strongly disagree. To assess the acceptability of the developed instructional material, a questionnaire that consists of five (5) criteria was used. The questionnaire determined the level of agreement of the student-respondents on the acceptability of the instructional material in terms of: (1) learning objectives; (2) accuracy; (3) clarity of the material; (4) appeal of the material; and (5) usability.

The data gathering procedure involved two (2) phases. During the first phase, the researcher administered the achievement test that was taken as the pretest and posttest before and after the student - respondents utilized the context-based video instruction respectively. The said achievement test was uploaded through a learning management system (LMS) (i.e. Schoology). The achievement test was first administered before the utilization of the said material to evaluate the prior existing knowledge the students already possessed about the concept dealing with cell biology through the use of the following descriptive rating: The students' scores were gathered since these data were used in the subsequent procedures. After the first semester of utilizing the context-based video instruction, the posttest was administered that was given to each student-respondent to see what has been assimilated with regards to the said topic. Afterwards, the test results were collected. Each Grade 11 studentrespondent accessed the context-based video instructions in cell biology through a Youtube Channel created by the researcher. The researcher utilized the said context-based video instruction as the main educational material in order to deliver the topic. The context-based video instruction was used by the researcher among the student-respondents during the instruction under the distance learning. The researcher utilized the said material during the first semester of school year 2020 - 2021. The researcher administered the questionnaire on the level of acceptability through the use of Google form to the Grade 11 student-respondents at the end of the first semester. Each student-respondent accessed the said questionnaire. Afterwards, their responses were assessed and evaluated to determine the level of acceptability of the instructional material. Thus, the level of acceptability of the students 
towards the developed context-based video instruction based on the criteria indicated in the said questionnaire was determined.

\section{RESULTS AND DISCUSSION}

\section{Results}

This part presents the results of this study. The gathered data, with the corresponding explanations, analysis and interpretations are discussed in this part of the research paper. The mean percentage score (MPS) of pretest results on the level of conceptual understanding in cell biology is shown in Table 1 .

Table 1. Mean Percentage Score (MPS) of Pretest Results on the Level of Conceptual Understanding in Cell Biology

\begin{tabular}{|c|c|c|c|c|c|c|c|c|c|}
\hline Topic & $\mathbf{N}$ & $\begin{array}{l}\text { Total } \\
\text { Item }\end{array}$ & $\begin{array}{l}\text { High } \\
\text { est } \\
\text { Score } \\
\end{array}$ & $\begin{array}{l}\text { Lowe } \\
\text { st } \\
\text { Score } \\
\end{array}$ & $\begin{array}{l}\text { Total } \\
\text { Score }\end{array}$ & $\begin{array}{c}\text { Standard } \\
\text { Deviatio } \\
\text { n }\end{array}$ & Mean & $\underset{\mathbf{S P}}{\mathrm{MP}}$ & $\begin{array}{c}\text { Concept } \\
\text { Understanding } \\
\text { Level } \\
\end{array}$ \\
\hline $\begin{array}{l}\text { Cell } \\
\text { Theory }\end{array}$ & 72 & 13 & 12 & 0 & 547 & 2.94 & 7.60 & $\begin{array}{c}58.4 \\
4 \%\end{array}$ & $\begin{array}{l}\text { Partial } \\
\text { Understanding with } \\
\text { specific } \\
\text { Misconceptions }\end{array}$ \\
\hline $\begin{array}{l}\text { Cellular } \\
\text { Structure } \\
\text { and } \\
\text { Functions }\end{array}$ & 72 & 45 & 35 & 0 & 1351 & 7.84 & 18.76 & $\begin{array}{c}41.7 \\
0 \%\end{array}$ & $\begin{array}{l}\text { Partial } \\
\text { Understanding with } \\
\text { Specific } \\
\text { Misconceptions }\end{array}$ \\
\hline $\begin{array}{l}\text { Animal } \\
\text { and Plant } \\
\text { Cells }\end{array}$ & 72 & 15 & 15 & 0 & 863 & 2.55 & 11.97 & $\begin{array}{l}79.9 \\
1 \%\end{array}$ & $\begin{array}{l}\text { Partial } \\
\text { Understanding }\end{array}$ \\
\hline $\begin{array}{l}\text { Prokaryoti } \\
\mathrm{c} \text { and } \\
\text { Eukaryotic } \\
\text { Cells }\end{array}$ & 72 & 20 & 20 & 0 & 1073 & 4.79 & 14.90 & $\begin{array}{l}74.5 \\
1 \%\end{array}$ & $\begin{array}{l}\text { Partial } \\
\text { Understanding }\end{array}$ \\
\hline Mitosis & 72 & 79 & 54 & 0 & 1729 & 4.01 & 24.01 & $\begin{array}{c}30.4 \\
0 \%\end{array}$ & $\begin{array}{l}\text { Specific } \\
\text { Misconceptions }\end{array}$ \\
\hline Meiosis & 72 & 75 & 58 & 0 & 1472 & 17.10 & 20.44 & $\begin{array}{c}27.2 \\
6 \%\end{array}$ & $\begin{array}{l}\text { Specific } \\
\text { Misconceptions }\end{array}$ \\
\hline $\begin{array}{l}\text { Cell Cycle } \\
\text { Control } \\
\text { System }\end{array}$ & 72 & 30 & 10 & 0 & 160 & 2.85 & 2.22 & $\begin{array}{c}7.41 \\
\%\end{array}$ & No Understanding \\
\hline $\begin{array}{l}\text { Plasma } \\
\text { Membrane }\end{array}$ & 72 & 38 & 24 & 0 & 544 & 5.18 & 7.56 & $\begin{array}{l}19.8 \\
8 \%\end{array}$ & No Understanding \\
\hline $\begin{array}{l}\text { Cell } \\
\text { Transport } \\
\text { Mechanis } \\
\text { ms }\end{array}$ & 72 & 45 & 22 & 0 & 336 & 5.84 & 4.67 & $\begin{array}{l}10.3 \\
7 \%\end{array}$ & No Understanding \\
\hline $\begin{array}{l}\text { Overall } \\
\text { Result }\end{array}$ & 72 & 360 & 228 & 29 & 8075 & 44.07 & 112.15 & $\begin{array}{c}31.1 \\
5 \%\end{array}$ & $\begin{array}{l}\text { Specific } \\
\text { Misconceptions }\end{array}$ \\
\hline
\end{tabular}

The summary of values demonstrates that the two (2) topics "Animal and Cells" and "Prokaryotic and Eukaryotic Cells" have the highest MPS values of $\mathbf{7 9 . 9 1 \%}$ and $\mathbf{7 4 . 5 1 \%}$. These MPS values fall under the descriptive rating of "partial understanding." On the other hand, the topics such as "Cellular Structures and Functions" and the "Cell Theory" have corresponding MPS values of $\mathbf{4 1 . 7 0 \%}$, and $\mathbf{5 8 . 4 4 \%}$ respectively. These MPS values fall under the descriptive rating of "partial understanding with specific misconceptions." The topics "Mitosis" and "Meiosis" have MPS values of $\mathbf{3 0 . 4 0 \%}$ and $\mathbf{2 7 . 2 6 \%}$ respectively. These values imply that the learners have specific misconceptions about these two (2) types of cell 
division. Lastly, the learners have no understanding about the topics "Cell Cycle Control System" (7.41\%), "Plasma Membrane" (19.88\%), and "Cell Transport Mechanisms" $\mathbf{( 1 0 . 3 7 \% )}$ during the pre-assessment phase of the study. In general, the topics in cell biology obtained an overall MPS value of $\mathbf{3 1 . 1 5 \%}$. It implies that the student-respondents have specific misconceptions about the different concepts in the said topic prior to the utilization of the said learning digital resources. Table 2 shows the summary of values for testing significant differences between the pretest and posttest scores in cell biology.

Table 2. Significant Difference between the Pretest and Posttest Scores of the StudentRespondents in Cell Biology

\begin{tabular}{|c|c|c|c|c|c|c|c|c|c|c|c|}
\hline \multirow[b]{2}{*}{ Topic } & \multirow[b]{2}{*}{$\begin{array}{l}\text { Te } \\
\text { st }\end{array}$} & \multirow[b]{2}{*}{$\begin{array}{l}\text { High } \\
\text { est } \\
\text { Score }\end{array}$} & \multirow{2}{*}{$\begin{array}{l}\text { Lowe } \\
\text { st } \\
\text { Scor } \\
\text { e }\end{array}$} & \multirow{2}{*}{$\begin{array}{l}\text { Tot } \\
\text { al } \\
\text { Ite } \\
\text { ms }\end{array}$} & \multirow[b]{2}{*}{$\begin{array}{c}\text { Mea } \\
\mathbf{n}\end{array}$} & \multirow{2}{*}{$\begin{array}{l}\text { Standa } \\
\text { rd } \\
\text { Deviati } \\
\text { on }\end{array}$} & \multirow[b]{2}{*}{$\begin{array}{c}\text { Mean } \\
\text { Differe } \\
\text { nce }\end{array}$} & \multicolumn{2}{|c|}{ t-value } & \multirow[b]{2}{*}{$\begin{array}{c}\text { Decisi } \\
\text { on }\end{array}$} & \multirow[b]{2}{*}{$\begin{array}{c}\text { Rema } \\
\text { rk }\end{array}$} \\
\hline & & & & & & & & $\begin{array}{c}\text { calc } \\
.\end{array}$ & $\begin{array}{l}\text { ta } \\
\text { b. }\end{array}$ & & \\
\hline Cell & Pre & 12 & 0 & 13 & 7.60 & 2.94 & 5.12 & 30.0 & 1.9 & Reject & Signifi \\
\hline Theory & $\begin{array}{l}\text { Pos } \\
t\end{array}$ & 13 & 10 & 13 & 12.72 & 0.79 & & 1 & 9 & $\mathrm{H}_{0}$ & cant \\
\hline Cellular & Pre & 35 & 0 & 45 & 18.76 & 7.84 & 23.03 & 29.9 & 1.9 & Reject & Signifi \\
\hline $\begin{array}{l}\text { Structure } \\
\text { and } \\
\text { Functions }\end{array}$ & $\begin{array}{l}\text { Pos } \\
t\end{array}$ & 45 & 0 & 45 & 41.79 & 9.91 & & 2 & 9 & $\mathrm{H}_{0}$ & cant \\
\hline Animal & Pre & 15 & 0 & 15 & 11.97 & 2.55 & 1.97 & 8.96 & 1.9 & Reject & Signifi \\
\hline $\begin{array}{l}\text { and Plant } \\
\text { Cells }\end{array}$ & $\begin{array}{l}\text { Pos } \\
t\end{array}$ & 15 & 0 & 15 & 13.94 & 0.12 & & & 9 & $\mathrm{H}_{0}$ & cant \\
\hline $\begin{array}{l}\text { Prokaryoti } \\
\mathrm{c} \text { and }\end{array}$ & $\begin{array}{l}\text { Pre } \\
\text { Pos }\end{array}$ & $\begin{array}{l}20 \\
20\end{array}$ & $\begin{array}{l}0 \\
0\end{array}$ & $\begin{array}{l}20 \\
20\end{array}$ & $\begin{array}{l}14.90 \\
18.58\end{array}$ & $\begin{array}{l}4.79 \\
4.68\end{array}$ & 3.68 & $\begin{array}{c}13.1 \\
0\end{array}$ & $\begin{array}{c}1.9 \\
9\end{array}$ & $\begin{array}{c}\text { Reject } \\
\mathrm{H}_{0}\end{array}$ & $\begin{array}{c}\text { Signifi } \\
\text { cant }\end{array}$ \\
\hline $\begin{array}{l}\text { Eukaryoti } \\
\text { c Cells }\end{array}$ & $\mathrm{t}$ & & & & & & & & & & \\
\hline Mitosis & $\begin{array}{l}\text { Pre } \\
\text { Pos } \\
t\end{array}$ & $\begin{array}{l}54 \\
79\end{array}$ & $\begin{array}{l}0 \\
0\end{array}$ & $\begin{array}{l}79 \\
79\end{array}$ & $\begin{array}{l}24.01 \\
75.63\end{array}$ & $\begin{array}{l}14.01 \\
13.07\end{array}$ & 51.62 & $\begin{array}{c}54.8 \\
4\end{array}$ & $\begin{array}{c}1.9 \\
9\end{array}$ & $\begin{array}{c}\text { Reject } \\
\mathrm{H}_{0}\end{array}$ & $\begin{array}{c}\text { Signifi } \\
\text { cant }\end{array}$ \\
\hline Meiosis & $\begin{array}{l}\text { Pre } \\
\text { Pos } \\
\mathrm{t}\end{array}$ & $\begin{array}{l}58 \\
75\end{array}$ & $\begin{array}{l}0 \\
0\end{array}$ & $\begin{array}{l}75 \\
75\end{array}$ & $\begin{array}{l}20.44 \\
69.14\end{array}$ & $\begin{array}{l}17.10 \\
19.07\end{array}$ & 48.70 & $\begin{array}{c}35.2 \\
4\end{array}$ & $\begin{array}{c}1.9 \\
9\end{array}$ & $\begin{array}{c}\text { Reject } \\
\mathrm{H}_{0}\end{array}$ & $\begin{array}{c}\text { Signifi } \\
\text { cant }\end{array}$ \\
\hline $\begin{array}{l}\text { Cell Cycle } \\
\text { Control }\end{array}$ & $\begin{array}{l}\text { Pre } \\
\text { Pos }\end{array}$ & $\begin{array}{l}10 \\
30\end{array}$ & $\begin{array}{l}0 \\
0\end{array}$ & $\begin{array}{l}30 \\
30\end{array}$ & $\begin{array}{c}2.22 \\
27.92\end{array}$ & $\begin{array}{l}2.85 \\
5.92\end{array}$ & 25.70 & $\begin{array}{c}70.5 \\
4\end{array}$ & $\begin{array}{c}1.9 \\
9\end{array}$ & $\begin{array}{c}\text { Reject } \\
\mathrm{H}_{0}\end{array}$ & $\begin{array}{c}\text { Signifi } \\
\text { cant }\end{array}$ \\
\hline $\begin{array}{l}\text { System } \\
\text { Plasma }\end{array}$ & $\begin{array}{l}\mathrm{t} \\
\text { Pre }\end{array}$ & 24 & 0 & 38 & 7.56 & 5.18 & 27.59 & 61.1 & 1.9 & Reject & Signifi \\
\hline $\begin{array}{l}\text { Membran } \\
\mathrm{e}\end{array}$ & $\begin{array}{l}\text { Pos } \\
t\end{array}$ & 38 & 0 & 38 & 35.15 & 7.03 & & 4 & 9 & $\mathrm{H}$ & cant \\
\hline $\begin{array}{l}\text { Cell } \\
\text { Transport }\end{array}$ & $\begin{array}{l}\text { Pre } \\
\text { Pos }\end{array}$ & $\begin{array}{l}22 \\
45\end{array}$ & $\begin{array}{l}0 \\
0\end{array}$ & $\begin{array}{l}45 \\
45\end{array}$ & $\begin{array}{c}4.67 \\
42.19\end{array}$ & $\begin{array}{l}5.84 \\
8.94\end{array}$ & 37.52 & $\begin{array}{c}65.1 \\
7\end{array}$ & $\begin{array}{c}1.9 \\
9\end{array}$ & $\begin{array}{c}\text { Reject } \\
\mathrm{H}_{0}\end{array}$ & $\begin{array}{c}\text { Signifi } \\
\text { cant }\end{array}$ \\
\hline $\begin{array}{l}\text { Mechanis } \\
\mathrm{ms}\end{array}$ & $\mathrm{t}$ & & & & & & & & & & \\
\hline $\begin{array}{l}\text { Overall } \\
\text { Result }\end{array}$ & Pre & 228 & 29 & 360 & $\begin{array}{c}112.1 \\
5\end{array}$ & 44.07 & 224.92 & $\begin{array}{c}59.5 \\
7\end{array}$ & $\begin{array}{c}1.9 \\
9\end{array}$ & $\begin{array}{c}\text { Reject } \\
\mathrm{H}_{0}\end{array}$ & $\begin{array}{c}\text { Signifi } \\
\text { cant }\end{array}$ \\
\hline & $\begin{array}{l}\text { Pos } \\
t\end{array}$ & 360 & 13 & 360 & $\begin{array}{c}337.0 \\
7\end{array}$ & 61.47 & & & & & \\
\hline
\end{tabular}

The result demonstrates that the mean scores of the student-respondents in the pretest and posttest are as follows: (1) $\mathbf{7 . 6 0}$ and $\mathbf{1 2 . 7 2}$ (Cell Theory); (2) $\mathbf{1 8 . 7 6}$ and $\mathbf{4 1 . 7 9}$ (Cellular Structure and Functions); (3) 11.97 and 13.94 (Animal and Plant Cells); (4) 14.90 and 18.58 (Prokaryotic and Eukaryotic Cells); (5) 24.01 and 75.63 (Mitosis); (6) 20.44 and 69.14 (Meiosis); (7) 2.22 and 27.92 (Cell Cycle Control System; (8) 7.65 and 35.15 (Plasma Membrane); and (9) 4.67 and 42.19 (Cell Transport Mechanism). Likewise, the result demonstrates that out of 360 items, the overall mean score of the student-respondents is 
112.15 with a standard deviation of $\mathbf{4 4 . 0 7}$ while the overall mean score in the posttest is 337.07 with a standard deviation of 61.47 .

To determine if the mean difference is significant, $t$-test for dependent sample was used. It can be analyzed that the computed $t$-values for each topic are as follows: $\mathbf{3 0 . 0 1}$ (Cell Theory), 29.92 (Cellular Structure and Function), 8.96 (Animal and Plant Cells), 13.10 (Prokaryotic and Eukaryotic Cells), 54.84 (Mitosis), 35.24 (Meiosis), 70.54 (Cell Cycle Control System), 61.14 (Plasma Membrane) and 65.17 (Cell Transport System). As a result, the overall $t$-value of $\mathbf{5 9 . 5 7}$ is greater than the tabular value of 1.99. Based from the comparison of these values, the researcher rejected the null hypothesis.

Table 3. Weighted Mean Distribution on the Level of Acceptability of the Context-Based Video Instruction in Cell Biology

\begin{tabular}{ccc}
\hline Criteria & Weighted Mean Value & Descriptive Rating \\
\hline Learning Objectives & 3.92 & \\
Clarity & 3.91 & Strongly Agree (SA) \\
Accuracy & 3.93 & \\
Appeal & 3.83 & \\
Usability & 3.83 & \\
\hline
\end{tabular}

Table 3 presents the students' responses with regards to the acceptability level of the context-based video instruction in cell biology. The criteria learning objectives, clarity, accuracy, appeal, and usability obtained weighted mean values of $3.92,3.91,3.93,3.83$, and 3.83, respectively. These numerical values fall under the descriptive rating of "strongly agree."

\section{Discussions}

The two (2) topics "Animal and Cells" and "Prokaryotic and Eukaryotic Cells" have the highest MPS values that fall under the descriptive rating of "partial understanding." It means that student-respondents have already prior knowledge about the differences and similarities among these various types of cells. This finding can be attributed to the introduction of these topics during the discussion about the cell structures and functions. During the lesson proper using the context-based video instructions, each organelle was discussed as well as the type of cell (e.g., plant, animal, prokaryotic, eukaryotic cells) where they can be found. This statement confirms with the study in which the clarity criterion of the video presentation is an essential element to assist the learners to grasp the strong connections between topics and make relationship between what is taught and their own experiences (Newby, 2006).

On the other hand, the topics such as "Cellular Structures and Functions" and the "Cell Theory" fall under the descriptive rating of "partial understanding with specific misconceptions." Based on these results, these topics have been learned during the previous years to a smaller extent or degree prior to the use of the said video instruction material. This result may be due to lack of enough prior existing knowledge among the learners since these topics are too abstract in nature. These results are similar to the findings revealed that the abstract level of the concepts as reasons for encountering difficulties in conceptual understanding in biology (Zeidan, 2010). Another reason for such difficulty is that biology learning is generally based on memorization. As a result, it makes biology hard for the students to learn (Cimer, 2004; Durmaz, 2007; Saka, 2006). Adding, the continuation of these problems makes the students to become more passive rather than active learners. It does not foster meaningful learning and long-term information retention of some abstract concepts in biology (Ahmed, 2009; Ahmed \& Abimbola, 2011; Umar, 2011). 
The learners have specific misconceptions about these two (2) types of cell division "Mitosis" and "Meiosis." These findings may be attributed to the complexity of the processes involved in each phase of cell division. In the previous study, the topic about meiosis is a common source of difficulty among many biology students (Newman et al., 2012). Learners should have the acquired knowledge and understanding about the concepts like sexual reproduction, cell cycle, chromosomal structure, genetic variability as well as DNA replication. However, there are evidences in which the learners cannot make such connections among the topics stated above (Kalas et al., 2013). As a result, there is a difficulty in conceptual understanding about "meiosis." Specifically, learners misinterpret chromosomes all throughout the stages of meiosis like incorrect depictions of the sister chromatids (Dikmenli, 2010; Newman et al., 2012).

Lastly, the learners have "no understanding" about the topics "Cell Cycle Control System", "Plasma Membrane", and "Cell Transport Mechanisms" during the pre-assessment phase of the study. It can be inferred that these topics are not clear among the learners specifically the processes that are involved in connection to the cell cycle regulators, structures and functions of the plasma membrane, and the movement of materials across the plasma membrane. According to Duda (2016), students experience several difficulties in conceptual understanding because of the misinterpretation about the different natural phenomena in their everyday lives. The use of many vocabulary terms about life and living organisms in the colloquial language and the use of these terms in a meaning aside from the defined scientific equivalent was considered to be among the problems that make learning and teaching cell biology difficult (Gungor \& Ozkan, 2017).

In general, the topics in cell biology obtained an overall MPS value of $31.15 \%$. It implies that the student-respondents have specific misconceptions about the different concepts in the said topic prior to the utilization of the said learning digital resources. There is an incorrect relationship error among the different concepts, intuitive ideas or wrong views (Suparno, 2013). This idea can describe the difficulties in conceptual understanding of the topic which is strongly connected to misconceptions. The said digital resource material was designed to enhance the conceptual understanding in cell biology among the Grade 11 students through the application of context-based video instruction. It also describes the Most Essential Learning Competencies (MELCs), in which the students should be able to expound in-depth understanding dealing with the different concepts of those perceived difficult topics in the said specialized content. To attain the essential goals, the perceived difficult topics in cell biology were discussed in the context-based video instruction. To achieve the basic ideas and concepts for those perceived difficult topics the designed context-based video instruction contains real-life application of the different topics. The said material provides various diagrams, animations, texts, clear audio and other forms of visual aids to fulfill the wideranging continuum of learners with diverse learning styles.

Based from the results that were obtained, it was found out that the studentrespondents have specific misconceptions about the topics in cell biology. Hence, the said digital resource material is divided into nine (9) subtopics namely: Cell Theory, Cellular Structure and Functions, Animal and Plant Cells, Prokaryotic and Eukaryotic Cells, Mitosis, Meiosis, Cell Cycle Control System, Plasma Membrane, and Cell Transport System. These lessons served as the perceived topics in which the student-respondents have specific misconceptions. These lessons were based from the MELCs of General Biology 1 for the first semester. It was found out that the nature of the topic in cell biology is the main cause of such difficulty. Based from the previous related studies, the abstract level of the concepts is one of the primary reasons for encountering difficulties in conceptual understanding in biology. Another reason for such difficulty is that biology learning is generally based on memorization. In order to address these problems, the researcher adds a thorough and 
comprehensive discussion about the different processes involved within the cell's environment in relation to its structure, types, functions, reproduction, and the movement of substances across the plasma membrane. The video-instruction also demonstrates the use more images of these cell processes with the aid of animations and texts which make the topics to become more concretized since these processes are too abstract for them. In addition, the content of the video instructions incorporates the principle of meaningful learning. It indicates that the content of the digital resource material ensures that the there is a strong connection among the topics arranged from simple to complex therefore applying the spiral approach of the K to 12 Basic Education Curriculum.

On the other hand, the developed context-based video instruction consists of short presentations for each topic ranging from $2 \mathrm{~min}$ to $10 \mathrm{~min}$. This is to ensure that the learners can maximize their engagement time during the lectures. For instance, on average, students spent around $3 \mathrm{~min}$ on videos that are longer than $12 \mathrm{~min}$, which means that they engaged with less than a quarter of the content. Lastly, appropriateness of the language, general appearance of the teacher, quality of video, lighting, animation, and video transitions were some of the parameters considered in designing the video lectures. These were validated by teachers and ICT expert. It can be gleaned that the mean values for posttest are higher than the mean values of pretest. The standard deviation in the posttest is higher than that of the pretest since the accumulated scores during the posttest is higher than the pretest. This result reveals that the posttest scores are more widely distributed than the pretest scores. It can be inferred that there was a significant difference between the pretest and posttest scores of the student-respondents. It is evident that the gained scores in the posttest of the studentrespondents can be attributed to the context-based video instruction in the said specialized subject. It only indicates that the student-respondents greatly improved their conceptual understanding about the difficult concepts in cell biology. Hence, the context-based video instruction is a valid tool in addressing the misconceptions and wrong views with regards to the selected topics in cell biology.

The findings stated above are also similar to the discussions in previous study (Adegoke, 2010). It was emphasized that in order to ensure a captivating approach that will assists the learners to understand the different biological concepts, the use of multimedia presentations in visual and verbal formats with the integration of pictures, animations, texts, and narrations are essential. He also emphasized that through the use of this approach, learners can acquire motivation to learn thus retention of long-term information. Likewise, learners acquired better understanding as well as information retention and developed comprehension skills more as compared to the other groups during the discussion the use of multimedia specifically the use of video instructions (Starbek et al., 2010). Moreover, video lectures arouse the interest of the learners, enables them to learn basic science concepts, enhances lecture-discussion and students' comprehension, helps them easily understand the lesson, and provides meaningful examples, relevant information and visual presentation (Rodriguez \& Ang, 2020).

It connotes that the context-based video instruction in cell biology contains objectives that provide well-defined and specific learning tasks, as well as integrated values which are assessable and achievable following the content requirement of the subject matter. Ideal instructional objectives prescribed in the instructional materials describe an observable performance that can be measured by a teacher. Hence, all learners should be able to display the knowledge or skill characterized in the learning outcome at the conclusion of the course. In terms of clarity, it can be inferred that the context-based video instruction integrates the capacity of the instructional material to give instructions, which aids the learners to come to a clear and well-defined understanding of the material. Clarity of instructional material has been connected constantly with the increase in students' academic performance (Newby, 
2006). Clarity is an essential element to assist the learners to grasp the strong connections between topics and make relationship between what is taught and their own experiences. Another essential idea about clarity is the logical and systematic arrangement of instructional material to ensure understanding that could be learned and processed easily by a certain group of learners to achieve mastery of the concepts and ideas.

Accuracy refers to the important qualities of the learning instructional material to show truthfulness among the learning contents that can be found in the said material (Newby, 2006). The context-based video instruction consists of contents that refers to the words and statements that were used in explaining the topics and concepts of a certain subject matter. The context-based video instruction has the correctness of diagrams, illustrations, as well as the data presented for a more convenient clarification and understanding for all the key concepts and ideas prescribed in the learning material. In addition, accuracy includes appropriate procedures in order to explain the solution in a given word problem. Accuracy of instructional material has something to do with students' accomplishment since it plays a pivotal role to scaffold the students to comprehend and explain the different phenomena, facts, theories, laws and principles. Important to the concept of accuracy is the appropriateness of the instructional material for understanding in order to appreciate and be aware of the concepts and ideas.

Adding, the context-based video instruction has appeal among the studentrespondents. It can be attributed to the presence of visual effects, graphics, photographs and font styles that are legible in the digital resource material. It can be gleaned that there is an increase in the interest in learning because it provides different visual aids like graphic organizers that really helped them in understanding cell biology easily. Appeal to the target users means that all words are spelled correctly, all fonts are clear and readable, there are appropriate margins, all media and resources were linked to the instructional material that are available. Hence, this refers to the instructional materials' structure, design, and arrangement that will create the students' comfort and motivation (Newby, 2006). Moreover, if the learners perceived the instructional material not visually appealing, this may contribute to the negative effects related to low academic performance.

In terms of usability, the context-based video instruction helps the students to learn the difficult topics in cell biology because it improves the study habits and active involvement of the students in their own pace under distance learning. Usability includes the degree to which a learning instructional material can be used by the learners to attain the learning objectives with efficiency, effectiveness and satisfaction (Kienonen, 2008). Based on recent researches, usability basically refers to as the product's main features, which are assessed through learners' experiences with a self-evaluation questionnaire. Learners' personal observation of the instructional materials is equally relevant. Simply, learners make some evaluations about the instructional material when it fulfills their preliminary expectations and when tasks can be demonstrated easily. Hence, an ideal instructional material is finely adjusted to support the requirements, and necessities, as well as expectations and motivation of its target audience. If the learners' experiences are closely associated with the expectations, it will play an important role in the overall learning experience. The actual learning experience should match or surpass the expectations.

\section{CONCLUSION}

In the light of the findings, the following conclusions were the student-respondents need intervention materials to enhance their conceptual understanding in cell biology in order to correct specific misconceptions about the topic; the developed context-based video instruction in enhancing the conceptual understanding in cell biology is ready for adoption; 
the developed context-based video instruction in enhancing the conceptual understanding in cell biology is a valid tool in teaching General Biology 1; the developed context-based video instruction in enhancing the conceptual understanding is commendable for use. It should have the following parameters: learning objectives, clarity, accuracy, appeal, and usability.

\section{REFERENCES}

Abidah, A., Hidaayatullaah, H., Simamora, R., Fehabutar, D., \& Mutakinati, L. (2020). The Impact of Covid-19 to Indonesian Education and Its Relation to the Philosophy of "Merdeka Belajar." Studies in Philosophy of Science and Education, 1(1), 38-49. https://doi.org/10.46627/sipose.v1i1.9.

Achebe, A. E. (2008). Effect of videotape instructional package on achievement and retention in food and nutrition at senior secondary school level in Minna, Niger State. Journal of Science Teaching and Mathematics Education, 1(1), 33-39.

Adegoke, B. A. (2010). Integrating animations, narrations and textual materials for improving students' learning outcomes in senior secondary school physics. Electronic Journal of Research in Educational Psychology, 8(2), 725-748. https://core.ac.uk/download/pdf/143456409.pdf

Ahmed, M. A. (2009). Lecturers' assessment of difficulty levels of genetics concepts in Nigeria colleges of education. Journal Curriculum and Instruction, 7(1). https://www.researchgate.net/profile/Mulkah-Ahmed/amp\%0A\%0A.

Ahmed, M. A., \& Abimbola, I. O. (2011). Influence of teaching experience and school location on biology teachers' rating of the difficult levels of nutrition concepts in Ilorin, Nigeria. JOSTMED, 7(2), 52-61. https://jostmed.futminna.edu.ng/images/JOSTMED/VOLUME_72_APRIL_2011/1.JOSTMED-7_2_-April-2011.pdf\#page=63.

Alea, L. A., Miguel, F. F., Robledo, D. A. R., \& Alam, X. F. (2020). Teachers' covid-19 awareness, distance learning education experiences and perceptions towards institutional readiness and challenges. International Journal of Learning, Teaching and Educational Research, 19(6), 127-144. https://doi.org/10.26803/ijlter.19.6.8.

Bower, B., L. (2001). Distance Education: Facing the Faculty Challenge. Journal of Distance Learning Administration, 4(2), 1-6. http://citeseerx.ist.psu.edu/viewdoc/download?doi=10.1.1.458.7893\&rep=rep1\&type= pdf.

Campbell, S., Grossman, S., Kris, A., Kazer, M., \& Rozgonyi, J. (2010). Screen capture classes for student learning and success. EDULEARN10 Proceedings, 5579-5584.

Choi, J., \& Johnson, S. D. (2010). The effect of context-based video instruction on learning and motivation in online courses. American Journal of Distance Education, 19(4), 215-227. https://doi.org/10.1207/s15389286ajde1904_3.

Christo-Baker, E. A. (2004). Distance Education as a Catalyst for Change in Higher Education. Association of Small Computer Users in Education (ASCUE). https://eric.ed.gov/?id=ED490098.

Cimer, A. (2004). A study of Turkish biology teachers' and students'views of effective teaching in schools and teacher education. The University of Nottingham.

De Koning, B. B., Tabbers, H. K., Rikers, R. M., \& Paas, F. (2007). Attention cueing as a means to enhance learning from an animation. Applied Cognitive Psychology: The Official Journal of the Society for Applied Research in Memory and Cognition, 21(6), 731-746. https://doi.org/10.1002/acp.1346.

Dikmenli, M. (2010). Misconceptions of cell division held by student teachers in biology: A drawing analysis. Science Research Essay, 5, 235-247. 
Duda, H. J., \& Adpriaydi. (2020). Students' Misconception in Concept of Biology Cell. Anatolian Journal of Education, 5(1), 47-52. https://doi.org/10.29333/aje.2020.515a.

Durmaz, B. (2007). The Effects of the Concept Cartoons to the Success of the Students and Sensory Features in the Constructivist Science Teaching (Muğla Provincial, Administrative District Sample). Muğla University.

Ellington, A. J., \& Hardin, J. R. (2008). The use of video tutorials in a mathematical modeling course. Mathematics and Computer Education, 42(2), 109-117. https://www.redorbit.com/news/education/1405288/the_use_of_video_tutorials_in_a_ mathematical_modeling_course/.

Etobro, B. A., \& Fabinu, E. (2017). Students' perceptions of difficult concepts in biology in senior secondary schools in Lagos State. Global Journal of Educational Research, 16, 139-147. https://www.ajol.info/index.php/gjedr/article/view/162440.

Feladi, V., Hendriyani, Y., Dewi, I. P., Darni, R., \& Verawardina, U. (2020). The Profile of Technological Pedagogical and Content Knowledge of Information and Communication Technology Teachers. Test Engineering \& Management, 83, 16661673.

Fojtik, R. (2018). Problems of distance education. ICTE Journal, 7(1), 14-23. https://doi.org/10.2478/ijicte-2018-0002.

Gambari, A. I., Yaki, A. A., Gana, E. S., \& Ughovwa, Q. (2014). Improving secondary school students' achievement and retention in biology through video-based multimedia instruction. Insight: A Journal of Scholarly Teaching, 9, 78-95. https://eric.ed.gov/?id=EJ1035855.

Gambari, A. I., \& Zubairu, A. A. (2008). Impact of videotape instructional package on achievement and retention in primary science among primary pupils in Niger State, Nigeria. The 2nd SSSE Annual National Conference, Federal University of Technology, Minna, Nigeria.

Gardner, H. (1983). Frames of mind: The theory of multiple intelligences. Basic Books.

Ghilay, Y. (2017). ODL: Online Distance Learning of quantitative courses in higher education. Advances in Social Sciences Research Journal, 4(18), 62-72. https://papers.ssrn.com/sol3/papers.cfm?abstract_id=3736662.

Ghilay, Y. (2018). Math courses in higher education: Improving learning by screencast technology. GSTF Journal on Education (JEd), 4(2), 1-6. https://eric.ed.gov/?id=EJ1098601.

Gungor, S. N., \& Ozkan, M. (2017). Evaluation of the concepts and subjects in biology perceived to be difficult to learn and teach by the pre-service teachers registered in the pedagogical formation program. European Journal of Educational Research, 6(4), 495-508. https://doi.org/10.12973/eu-jer.6.4.495.

Hadiprayitno, G., Muhlis, H., \& Kusmiyatni, A. (2019). Problems in learning biology for senior high schools in Lombok Island. The International Seminar on Bioscience and Biological Education. https://doi.org/10.1088/1742-6596/1241/1/012054.

Harris, J. B., \& Hofer, M. J. (2011). Technological pedagogical content knowledge (TPACK) in action: A descriptive study of secondary teachers' curriculum-based, technologyrelated lnstructional planning. Journal of Research on Technology in Education, 43(3), 211-229. https://doi.org/10.1080/15391523.2011.10782570.

Hartsell, T., \& Yuen, S. C. (2006). Video streaming in online learning. AACE Journal, 14(1), 31-43. https://www.learntechlib.org/p/6152/.

Höffler, T. N., \& Leutner, D. (2007). Instructional animation versus static pictures: A metaanalysis. Learning and Instruction, 17(6), 722-738. https://doi.org/10.1016/j.learninstruc.2007.09.013.

Kalas, P., O’Neill, A., Pollock, C., \& Birol, G. (2013). Development of a Meiosis Concept 
Inventory. $\quad C B E$ Life Science Education, 12, 655-664. https://www.lifescied.org/doi/abs/10.1187/cbe.12-10-0174.

Kebritchi, M., Lipschuetz, A., \& Santiague, L. (2017). Issues and Challenges for Teaching Successful Online Courses in Higher Education: A Literature Review. Journal of Educational Technology Systems, 46(1), 4-29. https://doi.org/10.1177/0047239516661713.

Kienonen, T. (2008). One-dimensional usability - influence of usability on consumers' product preference. Gummerus Company.

Lee, M. J. W., Pradhan, S., \& Dalgarno, B. (2008). The effectiveness of screencasts and cognitive tools as scaffolding for novice object-oriented programmers. Journal of Information Technology Education, 7, 61-80. https://www.learntechlib.org/p/111372/.

Mapuva, J. (2009). Confronting challenges to e-learning in Higher Education Institutions. Journal of Education and Development Using ICT, 5(3), 101-114. https://www.learntechlib.org/p/42282/.

Mathew, I., R., \& Ebelelloanya, J. (2016). Open and distance learning: Benefits and challenges of technology usage for online teaching and learning in Africa. Conference Proceedings \& Working Papers.

Mavrikaki, E., Koumparou, H., Kyriakoudi, M., Papacharalampous, I., \& Trimandili, M. (2012). Greek secondary school students' views about biology. International Journal of Environmental \& Science Education, 7(2), 217-232. https://eric.ed.gov/?id=EJ990517.

Mayer, R. E. (2009). Multimedia learning (2nd ed.). Cambridge University Press.

Musingafi, M., Mapuranga, B., Chiwanza, K., \& Zebron, S. (2015). Challenges for open and distance learning (odl) students: Experiences from students of the Zimbabwe open university. Journal of Education and Practice, 6(18), 59-67. https://eric.ed.gov/?id=EJ1079750.

Newby, T. J. (2006). Evaluation of students and materials in educational technology for teaching and learning. Merrill Company.

Newman, D. L., Catavero, C. M., \& Wright, L. K. (2012). Students fail to transfer knowledge of chromosome structure to topics pertaining to cell division. CBE Life Sci Education, 11, 425-436. https://doi.org/10.1187/cbe.12-01-0003.

Nursyifa, A., Rahmadi, I. F., \& Hayati, E. (2020). TPACK Capability Preservice Teachers Civic Education in the Era of Industrial Revolution 4.0. JPI (Jurnal Pendidikan Indonesia), 9(1), 15. https://doi.org/10.23887/jpi-undiksha.v9i1.17982.

Nusir, S., Alsmadi, I., Al-Kabi, M., \& Shardqah, F. (2010). Designing an interactive multimedia learning system for the children of primary schools in Jordan. IEEE Global Engineering Education Conference, Amman, Jordan.

O'Donoghue, J., Singh, G., \& Green, C. (2004). A comparison of the advantages and disadvantages of IT Based education and the implication upon students. Interactive Educational Multimedia, $\quad 9,63-76$. https://dialnet.unirioja.es/servlet/articulo?codigo $=4544753$.

Pang, K. (2009). Video-driven multimedia, web-based training in the corporate sector: Pedagogical equivalence and component effectiveness. The International Review of Research in Open and Distance Learning, 10(3), 1-14.

Peterson, E. (2007). Incorporating screencasts in online teaching. The International Review of Research in Open and Distance Learning, 8(3). http://www.irrodl.org/index.php/irrodl/article/viewArticle/4 95/935.

Phillips, J. M., \& Billings, D. M. (2007). Using webcasts for continuing education in nursing. Journal of Continuing Education in Nursing, 38(4), 152-153. 
Rodriguez, J. N., \& Ang, R. S. (2020). The usefulness of a teacher-made video on science learning: A flipped classroom approach. Maestra, 2(1), 19-24.

Saka, A. (2006). The effect of $5 E$ model on removing science student teachers' misconceptions about genetics. Karadeniz Technical University.

Smith, J. G., \& Smith, R. L. (2012). Screen-capture instructional technology: A cognitive tool for designing a blended multimedia curriculum. Journal of Educational Computing Research, 46(3), 207-228. https://doi.org/10.2190\%2FEC.46.3.a.

Starbek, P., Eriavec, M. S., \& Peklai, C. (2010). Teaching genetics with multimedia results in better acquisition of knowledge and improvement in comprehension. Journal of Computer Assisted Learning, 26(3), 214-224. https://doi.org/10.1111/j.13652729.2009.00344.x.

Sugar, W., Brown, A., \& Luterbach, K. (2010). Examining the anatomy of a screencast: Uncovering common elements and instructional strategies. International Review of Research in Open and Distance Learning, 11(3), 1-20. https://www.erudit.org/en/journals/irrodl/1900-v1-n1-irrodl05136/1067660ar/abstract/

Suparno, P. (2013). Miskonsepsi dan Perubahan Konsep Dalam Pendidikan Fisika. Grasindo.

Sutiah, S., Slamet, S., Shafqat, A., \& Supriyono, S. (2020). Implementation of distance learning during the COVID-19 in Faculty of Education and Teacher Training. Cypriot $\begin{array}{lllll}\text { Journal of Educational } & \text { Science, } & 15(5), & 1204 & \end{array}$ https://doi.org/10.18844/cjes.v15i5.5151.

Traphagan, T., Kucsera, J. V., \& Kishi, K. (2010). Impact of class lecture webcasting on attendance and learning. Educational Technology Research \& Development, 58(1), 19-37. https://doi.org/10.1007/s11423-009-9128-7.

Umar, A. A. (2011). Effects of biology practical activities on students' process skill acquisition in Minna, Niger State, Nigeria. JOSTMED, 7(2), 118-126.

Walker, L. (2010). Quantifying the benefits of narrated screen capture videos. In C. H. Steel, M. J. Keppell, P. Gerbic, \& S. Housego (Eds.), Curriculum, Technology \& Transformation for an Unknown Future (pp. 1031-1034). Proceedings Ascilite 2010.

Zeidan, A. (2010). The relationship between grade 11 Palestinian attitudes toward biology and their perceptions of the biology learning environment. International Journal in Science and Mathematics Education, 8, 783-800. https://doi.org/10.1007/s10763-0099185-8. 